\title{
The Late Cretaceous Klepa basalts in Macedonia (FYROM)- Constraints on the final stage of Tethys closure in the Balkans
}

\author{
Dejan Prelević $^{1,2}$ (D) $\mid$ Simon Wehrheim ${ }^{2}$ | Magnus Reutter ${ }^{2}$ | Rolf L. Romer ${ }^{3}$ | \\ Blažo Boev $^{4}$ | Milica Božović ${ }^{2}$ | Paul van den Bogaard ${ }^{5}$ | Vladica Cvetković ${ }^{1}$ | \\ Stefan M. Schmid ${ }^{6}$
}

${ }^{1}$ Faculty of Mining and Geology, University of Belgrade, Belgrade, Serbia

${ }^{2}$ Institute of Geological Sciences, University of Mainz, Mainz, Germany

${ }^{3}$ Deutsches GeoForschungsZentrum,

Potsdam, Germany

${ }^{4}$ Goce Delčev University, Štip, FYRO Macedonia

${ }^{5}$ GEOMAR Helmholtz-Zentrum für Ozeanforschung Kiel, 1-3 Wischhofstraße, Kiel, Germany

${ }^{6}$ Institut für Geophysik ETH, Zürich, Switzerland

Correspondence

Dejan Prelević, Faculty of Mining and Geology, University of Belgrade, Belgrade, Serbia.

Email: dejan.prelevic@rgf.bg.ac.rs

Funding information

University of Mainz Forschungs Fond;

Serbian Ministry of Education, Science and Technological Development, Grant/Award Number: 176016; Serbian Academy of Sciences and Arts, Grant/Award Number: F17, F9

\begin{abstract}
The waning stage(s) of the Tethyan ocean(s) in the Balkans are not well understood. Controversy centres on the origin and life-span of the Cretaceous Sava Zone, which is allegedly a remnant of the last oceanic domain in the Balkan Peninsula, defining the youngest suture between Eurasia- and Adria-derived plates. In order to investigate to what extent Late-Cretaceous volcanism within the Sava Zone is consistent with this model we present new age data together with trace-element and $\mathrm{Sr}-\mathrm{Nd}$ $\mathrm{Pb}$ isotope data for the Klepa basaltic lavas from the central Balkan Peninsula. Our new geochemical data show marked differences between the Cretaceous Klepa basalts (Sava Zone) and the rocks of other volcanic sequences from the Jurassic ophiolites of the Balkans. The Klepa basalts mostly have $\mathrm{Sr}-\mathrm{Nd}-\mathrm{Pb}$ isotopic and trace-element signatures that resemble enriched within-plate basalts substantially different from Jurassic ophiolite basalts with MORB, BAB and IAV affinities. Traceelement modelling of the Klepa rocks indicates $2 \%-20 \%$ polybaric melting of a relatively homogeneously metasomatised mantle source that ranges in composition from garnet Iherzolite to ilmenite+apatite bearing spinel-amphibole Iherzolite. Thus, the residual mineralogy is characteristic of a continental rather than oceanic lithospheric mantle source, suggesting an intracontinental within-plate origin for the Klepa basalts. Two alternative geodynamic models are internally consistent with our new findings: (1) if the Sava Zone represents remnants of the youngest Neotethyan Ocean, magmatism along this zone would be situated within the forearc region and triggered by ridge subduction; (2) if the Sava Zone delimits a diffuse tectonic boundary between Adria and Europe which had already collided in the Late Jurassic, the Klepa basalts together with a number of other magmatic centres represent volcanism related to transtensional tectonics.
\end{abstract}

\section{1 | INTRODUCTION AND SETTING}

The Balkan region occupies an important segment of the AlpineHimalayan collisional orogenic belt and consists of several Phanerozoic mobile belts (e.g., Cvetković, Prelević, \& Schmid, 2016; Schmid et al., 2008) (Figure 1). The dominant geological structure crossing the Balkan Peninsula is an axial belt originally named "Vardar Zone" by Kossmat (1924) who characterised this zone as "a steep belt made up of a large variety of intercalated continental and ophiolitic slivers that, in Macedonia, separate the culmination of the Pelagonian Massif in the west from the culmination of the Serbo-Macedonian Massif and the Rhodope in the east" (Figure 1). In modern 


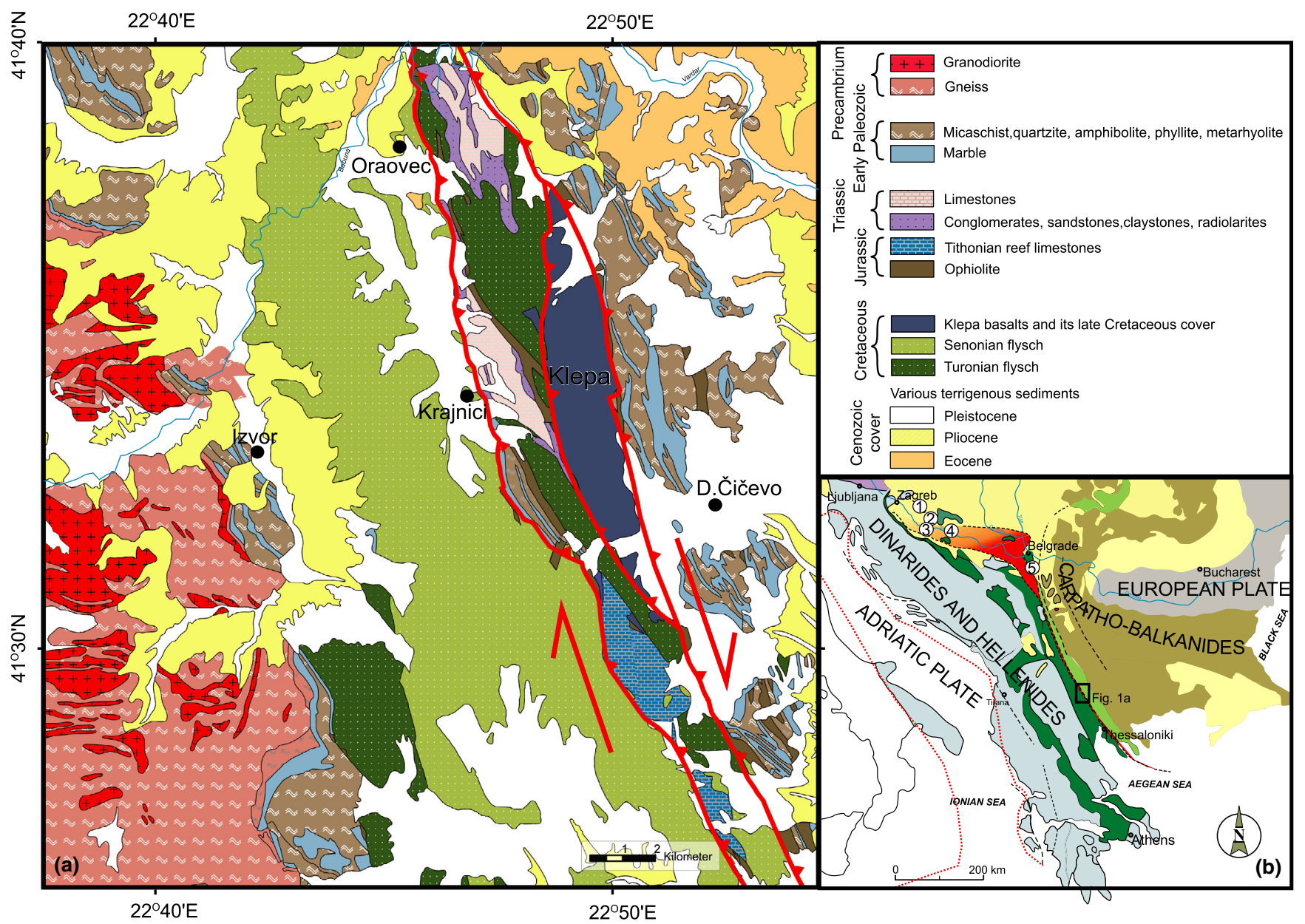

FIGURE 1 (a) Simplified geological map of the Klepa block and surrounding areas within the Sava Zone of Macedonia (FYROM), based on the Geological Map of Yugoslavia 1:100,000 (sheet Prilep) with the modifications of Robertson et al. (2013). Red lines indicate tectonic contacts formed in a dextrally transgressional environment. (b) Simplified tectonic map of the Balkan Peninsula after Schmid et al. (2008), depicting from west to east Adria-related units (pale blue) and W Vardar ophiolites (dark green), Sava suture (red), European units (brown and grey), E-Vardar ophiolites (pale green) and Cenozoic cover (yellow). Numbered circles indicate discrete Cretaceous magmatic centres along the Sava Zone mentioned in the text (1: Moslovačka Gora; 2: Prosara; 3: Kozara; 4: Požeška Gora; 5: Tešića Majdan) [Colour figure can be viewed at wileyonlinelibrary.com]

terms this belt separates a younger SW-verging nappe stack of the Dinarides derived from the Adriatic continental margin (Gondwana) in the west from an older and dominantly NE-facing nappe stack of the Carpatho-Balkan orogen derived from the European margin (Laurasia) in the east (Figure 1 inset). The Adriatic and European margins had developed in the Mesozoic, forming the northern branch of the Neotethys (e.g., Sengör \& Yilmaz 1981), which was closed in the Late Cretaceous to Early Cenozoic (e.g. Cvetković et al., 2016 and references therein). The loosely defined Vardar Zone in the sense of Kossmat (1924), therefore, must represent an important suture between the Adriatic and European margins.

The origin and the emplacement mechanisms of the Balkan ophiolites have been subject to vigorous debate particularly around the question of whether the different ophiolites were derived from a single or from several oceans (for discussions, see Schmid et al., 2008). In terms of geographical distribution, at least two subparallel ophiolite belts can be distinguished in the Balkans: an eastern one
(Eastern Vardar ophiolite belt) and a western one (Western Vardar ophiolite belt) (Cvetković et al., 2016; Schmid et al., 2008 and references therein). There is emerging consensus about the geodynamics and origin of the two Vardar belts: the Eastern Vardar belt is interpreted as a Jurassic back-arc basin that closed shortly after its opening (e.g., Božović et al., 2013; Gallhofer, von Quadt, Peytcheva, Schmid, \& Heinrich, 2015) and obducted towards the east (Schmid et al., 2008); the Western Vardar ophiolite belt is regarded as part of a huge piece of the Neotethys oceanic lithosphere, which was more or less uniformly obducted towards the west, that is, onto the passive margin of northern Gondwana (Schmid et al., 2008). After their emplacement, both ophiolitic belts underwent weathering and erosion in the Late Jurassic/Early Cretaceous (Cvetković et al., 2016 and references therein).

In recent years the controversy regarding the waning stage(s) of the life of the Tethyan ocean(s) has slowly overshadowed any debate over the origin of the ophiolites and their emplacement 
mechanisms. Some authors consider Europe-Adria collision to have occurred in the Late Jurassic (e.g., Csontos \& Vörös, 2004), whereas others envisage that the final closure of the last Tethyan ocean happened at the end of the Cretaceous (Karamata, 2006; Robertson, Karamata, \& Šarić, 2009; Schmid et al., 2008; Ustaszewski et al., 2009) along the Sava Zone (or Sava suture zone) as mapped by Schmid et al. (2008). The discussion now centres on the existence, origin and life-span of this Cretaceous Sava Ocean (Ustaszewski et al., 2010), considered by many to contain a relic of the youngest Tethyan oceanic realm left behind after the major convergence in the Jurassic (e.g., Karamata, 2006; Robertson et al., 2009; Schmid et al., 2008). In this context the Sava suture may possibly host remnants of a wider Late Cretaceous oceanic domain whose eastern continuation may be found in, for example, the Cyclades Islands (Fu et al., 2012), in Crete (Langosch et al., 2000) and in Turkey (inset of Figure 1).

In this study we focus on the geochemistry, petrology and age data of basaltic lavas from newly discovered "ophiolitic" outcrops in Macedonia called the Klepa block for which our new age data reveal a Late Cretaceous age, meaning that it potentially may represent a piece of oceanic lithosphere belonging to the alleged Sava Ocean. Our aim is to compare this occurrence with ophiolitic counterparts in Macedonia and further north in Serbia and Bosnia and to discuss their petrogenesis in the light of viable geodynamic scenarios.

\section{2 | GEOLOGY OF THE KLEPA BLOCK}

The Klepa block is a $10 \mathrm{~km}$ long (NNW-SSE) 1-2 km wide (WSWENE) and $1150 \mathrm{~m}$ high inselberg, which is dominantly composed of basaltic rocks occasionally covered by a thin veneer of sedimentary rocks not mappable at conventional scales (Figure 1). The bulk of the basaltic sequence consists of pillows, sheet flows, dikes and cumulates (Appendix S1, Figure 1). Due to the low aspect ratio of the lavas the volcanic structure may be interpreted as a relict shield volcano. Along the eastern margin the volcanic rocks are locally transgressed by slightly sheared conglomerates containing sub-angular to subrounded quartzite, schist and limestone clasts, as well as by fine-grained marlstones and sandstones. To the north along the eastern and western margins the basaltic sequence is overlain by sheared reddish clay-rich Scaglia Rossa hemipelagic limestones (presumably Campanian, by analogy with the North Kozara Mts., Ustaszewski et al., 2009, 2010) that are covered by sandy (possibly Maastrichtian) conglomerates.

In the east the basaltic sequence is in subvertical tectonic contact with formations made up of a series of deformed and mylonitised (most probably Jurassic) ophiolitic mélange sequence, including serpentinite, gabbro and limestone blocks (Appendix S1, Figure 2), interlayered with a sequence of dominantly mylonitic marbles and mylonitic sericite schists with biotite and chlorite. The latter lithologies are interpreted as a part of the Palaeozoic Veles Series (Antic et al., 2016; Grubić \& Ercegovac, 1974) and represent the Palaeozoic part of the Circum-Rhodope belt (van Hinsbergen \& Schmid, 2012).
The intensity of deformation within the Veles Series increases considerably towards the contact with the Klepa block where lineations become subhorizontal and shear indicators suggest dextral strike slip. The formations west of the Klepa block are evidently also in tectonic contact with the adjacent units (Figure 1), which include TriassicJurassic cover, Turonian conglomerates and flysch, and slivers of serpentinites. These units may be attributed to the Jadar-Kopaonik thrust sheet (sensu Schmid et al., 2008) and involve the Mesozoic basement and cover of the Adriatic margin. Further west the JadarKopaonik thrust sheet is emplaced on top of Senonian flysch, which, together with Turonian conglomerates at its base, rests in stratigraphic contact directly on the basement of the Pelagonian Massif. All these sequences are strongly mylonitised and sheared, especially near the contact with the Klepa basaltic sequences.

\section{3 | ANALYTICAL TECHNIQUES}

We studied 29 samples from the Klepa volcanic rocks (Appendix S2) for major and trace elements and 12 samples for $\mathrm{Sr}, \mathrm{Nd}$ and $\mathrm{Pb}$ isotope analysis following the procedures described in Božović et al. (2013), including a thorough leaching procedure specially designed for ophiolitic basalts. Moreover, amphibole and feldspars from two samples were dated using the ${ }^{40} \mathrm{Ar} /{ }^{39} \mathrm{Ar}$ method following the procedure described by Božović et al. (2013). Reproducibility of the trace elements, internal and external standards and the quality of the isotopic analyses are shown in detail in Božović et al. (2013).

\section{RESULTS}

Based on the petrography, mineralogy and geochemistry of the lavas four rock types were identified: subalkaline transitional basalts, alkaline basalts, Ti-amphibole-bearing microgabbros and trachyandesites/ trachytes (Figure 3 and 4 in Appendix S1). The rocks are porphyritic with phenocrystic subhedral olivine pseudomorphs, augite, plagioclase and in some samples amphibole (for mineral chemistry, including BSE images, major- and trace-element analyses, see Appendix S3). The groundmass is composed of tabular and acicular plagioclase (partly albitised), amphibole and in most cases completely altered glass. Secondary minerals include chlorite, calcite, epidote, sericite, albite and clays.

The Klepa basalts have a HFSE and REE signature that resembles trace-element enriched within-plate basalts with low $\mathrm{Zr} / \mathrm{Nb}$ (4-8), high $\mathrm{Zr} / \mathrm{Hf}(>40), \mathrm{Nb} / \mathrm{Yb}$ (up to 60) and $\mathrm{Nb} / \mathrm{Ta}$ (up to 20) and variable $\mathrm{La} / \mathrm{Yb}$ (Appendix S2). In a Th/Yb vs. $\mathrm{Nb} / \mathrm{Yb}$ diagram (Figure $2 \mathrm{~b}$ ), the Klepa samples fall in the mantle array and are displaced from MORB towards OIB compositions (Pearce, 2008). Despite variable trace-element ratios the lavas show relatively uniform $\mathrm{Nd}$ and $\mathrm{Pb}$ isotopic compositions with a limited range of ${ }^{143} \mathrm{Nd} /{ }^{144} \mathrm{Nd}_{\mathrm{i}}$ (0.51287-0.51289) plotting outside the MORB array (Figure 2c). The $\mathrm{Pb}$ isotope compositions of the Klepa lavas are also invariable with ${ }^{206} \mathrm{~Pb} /{ }^{204} \mathrm{~Pb} \sim 19.6$ and high ${ }^{207} \mathrm{~Pb} /{ }^{204} \mathrm{~Pb}$ ratios that range between 
15.60 and 15.65 and fall within the OIB field (Figure 2d). Only $\mathrm{Sr}$ isotopes show slight variations, which are interpreted below as having been produced by alteration of the groundmass glass present in most of the investigated samples (Figure 2c).

${ }^{40} \mathrm{Ar} /{ }^{39} \mathrm{Ar}$ incremental heating experiments were conducted on two samples of separated amphibole and feldspar phenocrysts. The results are presented in Appendix S4. The measurements yielded plateau ages at $80.4 \pm 0.9$ and $80.7 \pm 0.5 \mathrm{Ma}$, respectively, based on more than $50 \%$ Ar released.

\section{DISCUSSION}

\subsection{No evidence for MORB/BAB or IA affinity of the Klepa volcanics}

Our new geochemical data show marked differences between the Klepa basalts and the volcanic rocks of other Balkan (Jurassic) ophiolites in Serbia and Macedonia (FYROM) (Figure 2a,b). In general the Klepa basalts have HFSE signatures that resemble those shown by trace-element enriched within-plate basalts, which, in turn, substantially differ from ophiolite samples of MORB and BAB affinity. In addition, no arc signature is seen in the geochemistry of the Klepa lavas. In contrast, the bulk of the oceanic crust of Vardar Tethys has petrological and geochemical compositions characteristic of rocks of mid-ocean ridge or back-arc origin (MORB and BAB) (Božović et al., 2013; Robertson \& Karamata, 1994). These lavas have variously depleted LREEs relative to HREEs and radiogenic ${ }^{143} \mathrm{Nd} /{ }^{144} \mathrm{Nd}$ values similar to those of a BAB/MORB source. Some of the ophiolites of the Eastern Vardar subordinately contain lavas that show a pronounced subduction-related geochemical signature (Marroni et al., 2004; Saccani et al., 2008; Božović et al., 2013) and contain boninites, adakites and keratophyres that formed in the fore-arc region of an island-arc system. Most of these arc lavas are interpreted to have been generated during subduction initiation within a back-arc basin (Božović et al., 2013). If we exclude the subordinate occurrences of OIB-like lavas in the Greek eastern Vardar (Saccani et al., 2008) and in the Dinarides (Popević, Memović, Zakariadze, Milovanović, \& Karamata, 2005), none of the Jurassic ophiolites of the Balkans have geochemical and petrological associations similar to those of the Late-Cretaceous volcanic rocks of the Sava zone.

\subsection{Source mineralogy of the Klepa basalts and its significance}

The variable composition of the Klepa magmas seen in simple bivariate diagrams (e.g. $\mathrm{SiO}_{2}$ and $\mathrm{TiO}_{2}$ vs. $\mathrm{MgO}$ ) clearly demonstrates that more evolved Klepa lavas underwent Ol-Cpx-PI-Ti mineral fractionation (Appendix S5). However, the most primitive samples (screened for $>3 \% \mathrm{MgO}$ ) show significant geochemical variation that is related to the mantle-melting processes. For instance, distinct fractionation of LREE and MREE from HREE is largely related to melting of the mantle source as fractional crystallization of typical basalt phases does not modify the REE pattern significantly (e.g., Ellam, 1992; McKenzie \& O’Nions, 1991). Klepa basalts show a considerable fractionation of $\mathrm{La} / \mathrm{Yb}$ and $\mathrm{La} / \mathrm{Nd}$ when plotted against a strongly incompatible element, for example Th (Appendix S5), indicating a decrease in the degree of melting or a variation in the metasomatic enrichment of LREE (McKenzie \& O'Nions, 1991).

The primitive Klepa magmas show invariably radiogenic ${ }^{206} \mathrm{~Pb} /{ }^{204} \mathrm{~Pb}$ at relatively high ${ }^{207} \mathrm{~Pb} /{ }^{204} \mathrm{~Pb}$ and high ${ }^{143} \mathrm{Nd} /{ }^{144} \mathrm{Nd}$ (Figure 2c,d). Together with trace-element patterns showing regular variations of HFSE, this indicates that variable degrees of partial melting of a relatively homogeneously enriched mantle source rather than a variably metasomatised mantle played a crucial role in the petrogenesis of these rocks (Cebria \& Lopez Ruiz, 1996; Cebria et al., 2000). We modelled mantle melting using the inverse method (Cebria \& Lopez Ruiz, 1996; Class \& Goldstein, 1997; Treuil \& Joron, $1975)$ to estimate major melting parameters and to model variable degrees of melting of different types of homogeneous mantle based on the mineralogical constraints obtained from the melting model. Below is a brief summary of the modelling method and results we obtained. A detailed description of the method is included in Appendix S6.

In general, the concentration of trace elements in the melt becomes effectively buffered by the residual mineral assemblages. This buffering effect is seen in the relatively low and uniform concentrations of the elements that are highly concentrated in some residual phases. In contrast, the most incompatible elements, which are not buffered by the residual minerals, will show the largest compositional range. By plotting the most incompatible element against the elements buffered by some residual phases and comparing the slopes of the regression lines, we can broadly estimate the extent of depletion and indirectly determine the composition of the residual phases (Appendix S6).

The variation in the geochemical data implies that Th is the most incompatible element in the mantle source of the Klepa lavas. The relative degree of incompatibility of other elements (Figure 3a; see Appendix S6 for details) shows that $U$ and La behave similarly and that incompatibility decreases in the order $\mathrm{Nb}, \mathrm{Ta}, \mathrm{Ba}, \mathrm{Dy}, \mathrm{Yb}, \mathrm{P}$ to $\mathrm{Ti}$. (Figure 3a inset), which suggests the presence of several residual minerals in the mantle source: amphibole will retain $\mathrm{Ba}$ (and $\mathrm{Rb}$ ), $\mathrm{P}$ will be held by apatite, and $\mathrm{Nb}$, $\mathrm{Ta}$ and $\mathrm{Ti}$ will be kept by some $\mathrm{Ti}$ phase, most probably ilmenite. By using the extents of element incompatibility quantified by their enrichment ratios (E) (Figure 3a), we obtained negative anomalies for $\mathrm{Rb}, \mathrm{Ba}, \mathrm{Nb}, \mathrm{Ta}, \mathrm{P}$ and $\mathrm{Ti}$, confirming the presence of residual amphibole, apatite and a Ti phase (ilmenite?). The most important outcome of this modelling is the recognition of several residual metasomatic minerals typically reported from the continental lithospheric mantle (e.g. Cvetković, Downes, Prelević, Jovanovic, \& Lazarov, 2004; lonov, Bodinier, Mukasa, \& Zanetti, 2002; lonov, Gregoire, \& Prikhodko, 1999; O'Reilly \& Griffin, 2000) but not usually found in the oceanic lithospheric mantle.

Fractionation of LREE/HREE may additionally indicate the presence of melts that formed in the garnet stability field (Ellam, 1992). 

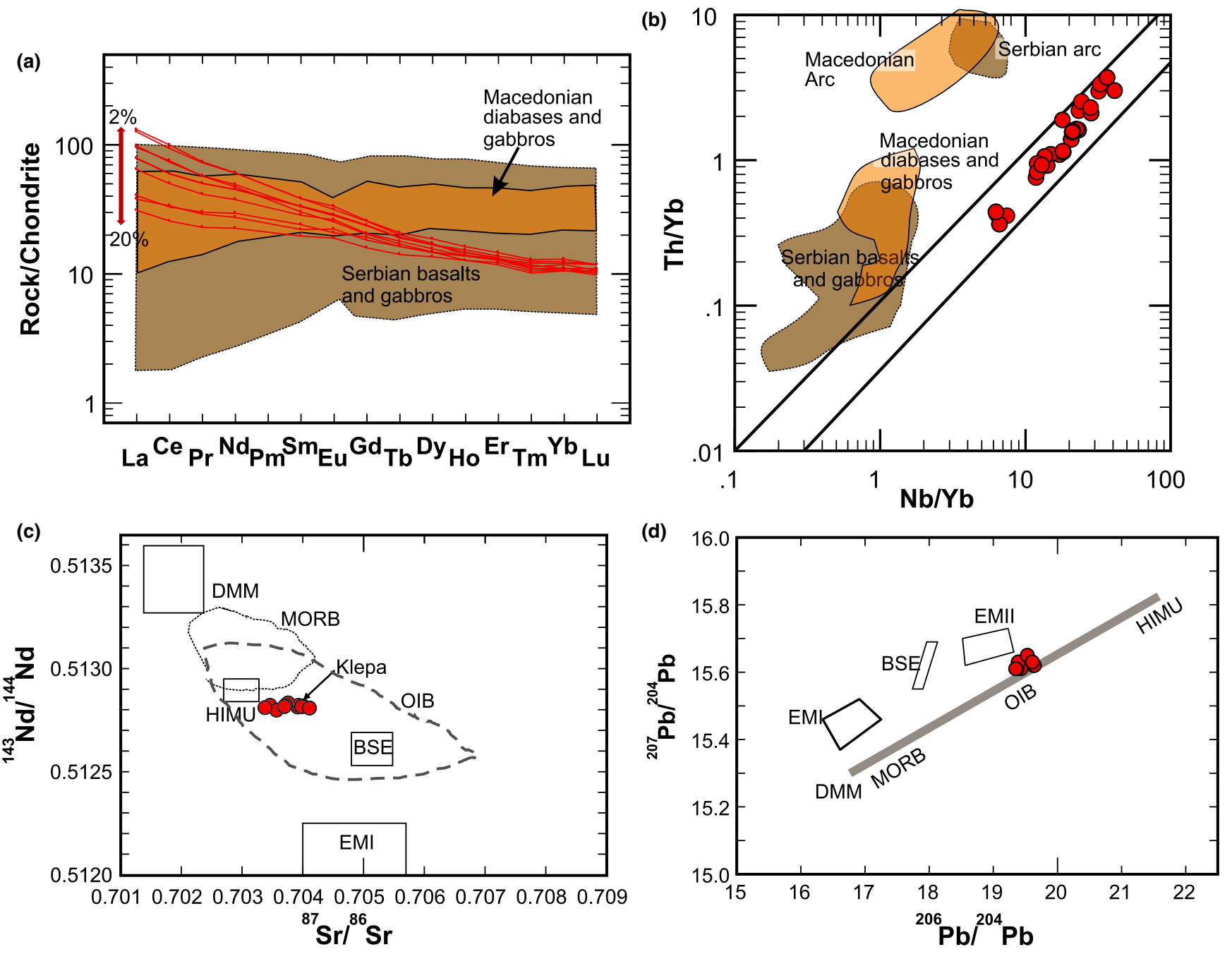

FIGURE 2 (a) Chondrite-normalised (Sun \& McDonough, 1989) concentrations of REE for selected samples from the Klepa basalts (red lines). Only samples with $\mathrm{MgO}>3 \mathrm{wt} \%$ are shown to demonstrate the mantle control on the range of REE pattern. For comparison, we plot the arrays for Serbian Jurassic ophiolitic basalts and gabbros and Jurassic diabase and gabbro from the East Vardar ophiolites in Macedonia (FYROM) (Božović et al., 2013 and references therein; Prelević unpublished). The red double arrow indicates the variation in LREE due to different extents of partial melting of a geochemically homogeneous mantle source. A rough estimation of the extent of partial melting is $2 \%-$ 20\%. This estimate is based on, Cebria \& Lopez Ruiz (1996) and Maaløe \& Pedersen (2003), who proposed that for highly incompatible elements whose partition index is close to zero $\left(D^{i} \approx 0\right)$, the simple batch melting equation can be approximated with $C_{m}^{i}=C_{o}^{i} / F$ $\left(C_{m}^{i}\right.$ - concentration of the highly incompatible element $i$ in the melt; $C_{o}^{i}$ - concentration of the highly incompatible element $i$ in the source; $\mathrm{F}$ - melting degree). Hence, the highest and lowest concentrations of the highly incompatible element are produced by the lowest $\left(\mathrm{F}_{\text {low }}\right)$ and highest $\left(F_{\text {high }}\right)$ melting degrees, respectively. As has been shown by Cebria \& Lopez Ruiz (1996) and Maaløe \& Pedersen (2003) for highly incompatible elements, we can approximate the relation formula, which enables us to estimate the relative range of the degree of melting $\left(\mathrm{F}_{\text {high }} / \mathrm{F}_{\text {low }}\right)$. Using this assumption and the Th and La variations, we estimate the relative range of the degree of melting for the Klepa rocks to be $\mathrm{F}_{\text {high }} / \mathrm{F}_{\text {low }} \approx 10$. (b) Nb/Yb vs. Th/Yb (Pearce \& Peate, 1995) for the Klepa basalts, with reference fields for Serbian Jurassic ophiolitic basalts and gabbros and Macedonian Jurassic ophiolitic diabases and gabbros (Božović et al., 2013 and references therein; Prelević unpublished). (c) and (d) $\mathrm{Sr}-\mathrm{Nd}$ and $\mathrm{Pb}$ isotopic variations in the igneous rocks of the Klepa basalts, respectively. Geochemical mantle components are based on Zindler and Hart (1986): DMM - depleted MORB mantle, HIMU - high $\mu$; BSE - bulk silicate earth; EM I - enriched mantle 1; EM II - enriched mantle 2 [Colour figure can be viewed at wileyonlinelibrary.com]

Figure $3 \mathrm{~b}$ displays $\mathrm{La} / \mathrm{Yb}$ and $\mathrm{Dy} / \mathrm{Yb}$ ratios and confirms that the Klepa basalts may dominantly have originated from $2 \%-20 \%$ partial melting of an amphibole-apatite-ilmenite-bearing metasomatised mantle source within the spinel stability field. The restricted stability field of hydrous minerals in peridotite (Frost, 2006) limits this assemblage to the lithospheric mantle. However, the spreading of the data towards the garnet stability field in Figure 3b may be interpreted as the result of two-component mantle melting-mixing: one component tapped the (metasomatised lithospheric) mantle situated in the spinel stability field, and the second component is derived from the mantle located within the garnet stability field. In other words, we may propose a continuum between low-degree melting in the garnet stability field and high-degree melting of the metasomatised mantle in the spinel stability field. The invariable $\mathrm{Nd}$ and $\mathrm{Pb}$ isotopic signatures 

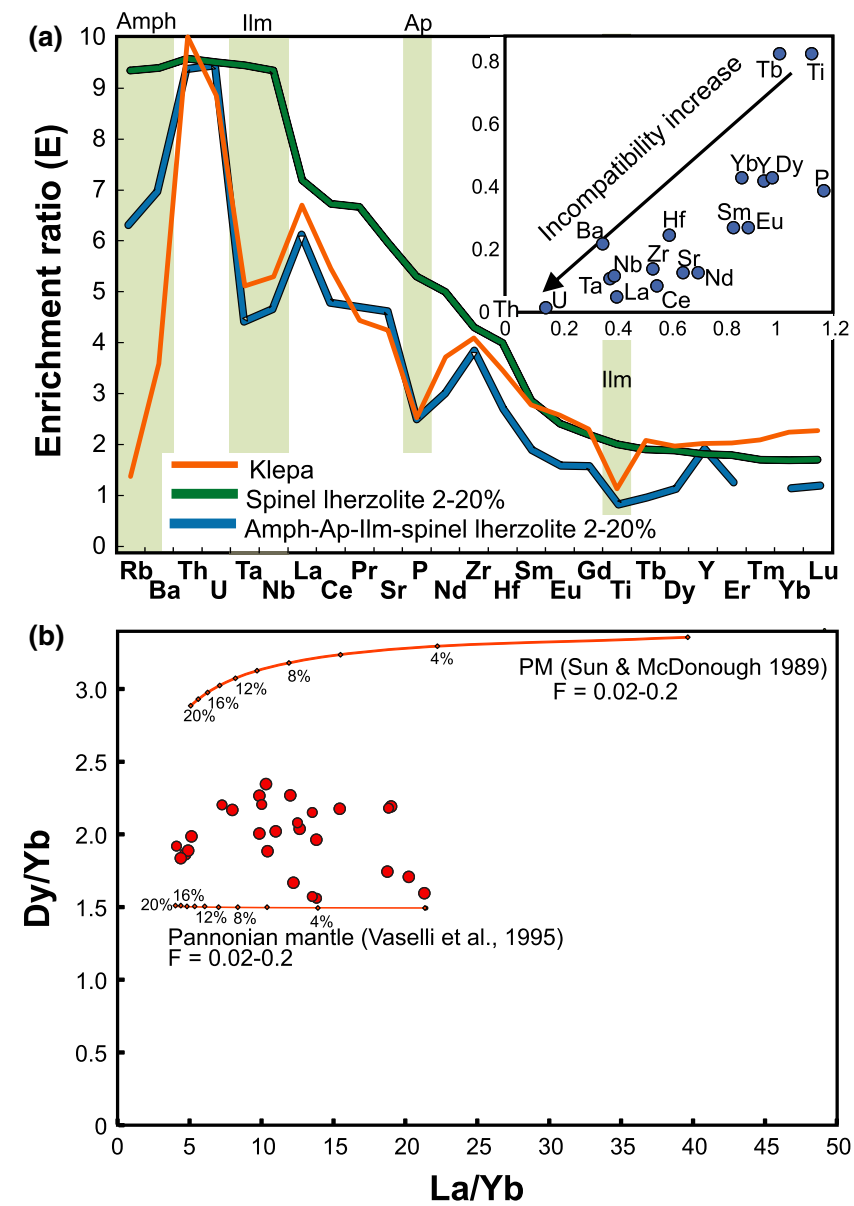

FIGURE 3 (a) Magma source mineralogy of the Klepa basalts (for details of the estimation of $E$ values refer to Appendix S6). The enrichment ratio $(E)$ pattern uses estimated $E$ values from Appendix S6. We also recalculated $E$ values for $2 \%-20 \%$ non-modal batch melting of spinel-Iherzolite and amphibole-apatite-ilmenitespinel-Iherzolite sources with the composition shown in the diagram; note that four troughs with low E values (pale green arrays) cannot be reproduced without residual amphibole (Amph), apatite (Ap) and Ti-phase (ilmenite - IIm) in the source. Modelling details including partition coefficients and modal contributions of different phases are presented in Appendix S6. Inset: Relative degree of incompatibility of trace elements relative to the Klepa mantle source mineralogy. For details, see Appendix S6; b) Results of trace-element modelling of primitive samples of Klepa basalts: La/Yb vs. Dy/Yb. Modelled trajectories are for non-modal, batch partial melts (Shaw, 1970) of garnet-facies Iherzolite $\left(\mathrm{Ol}_{0.60} \mathrm{Opx}_{0.25} \mathrm{Cpx}_{0.09} \mathrm{Grt}_{0.06}\right)$ that melts in the proportions $\left(\mathrm{Ol}_{0.12} \mathrm{Opx}_{0.25} \mathrm{Cpx}_{0.30} \mathrm{Grt}_{0.33}\right)$ and amphibole-apatiteilmenite-lherzolite from spinel-facies mantle (Appendix S6). Tick marks on the curves represent percentage of melt extracted $(20,18$, $16,14,12,10,8,6,4,2 \%)$. Source compositions: Primitive Mantle (PM) of McDonough (1990) and Pannonian metasomatised mantle of Vaselli et al. (1995) were chosen for partial melting scenarios. The partition coefficients used are presented in Appendix S6 [Colour figure can be viewed at wileyonlinelibrary.com]

may reflect the fact that melting of depleted mantle does not significantly contribute to the $\mathrm{Nd}$ and $\mathrm{Pb}$ budgets, which are dominated by the metasomatised mantle source. Note, mantle heterogeneities and/or melt mixing within the asthenospheric mantle source (Beier,
Stracke, \& Haase, 2007), which are typical in plume-related mantle melting, would result in a broader range of $\mathrm{Nd}$ and $\mathrm{Pb}$ isotopic compositions of the rocks.

\subsection{Unlocking the geodynamic significance: intracontinental rifting vs. a seamount ophiolitic origin for the Klepa basalts}

The identification of amphibole, apatite, ilmenite and potentially garnet in the source region of the Klepa lavas puts important constraints on the melting depth and indirectly on the type of mantle involved in the melting process. We interpret the crystallization of a number of metasomatic minerals in the mantle as a result of metasomatising effects of alkaline basaltic precursor melts (Pilet, 2015). Their presence is instrumental in lowering melting temperatures and indicates that the source region is dominantly situated within the lithospheric mantle (Frost, 2006). Furthermore, the data indicating the presence of garnet in the mantle source roughly constrain the depth of partial melting to reach the garnet stability field at 2530 kbars (Klemme, 2004 and references therein).

The following two geodynamic settings may account for the geochemical variation observed in the Klepa basalts:

1. The Klepa basalts show some geochemical characteristics of seamount basaltic magmas, similar to the origin recently proposed for the Cretaceous bimodal association in Kozara Mt. (Cvetković, Šarić, Grubić, Cvijić, \& Milošević, 2014) (Figure 1, inset). Unmetamorphosed (Yang, Li, Xiao, \& Tong, 2015) and metamorphosed (John et al., 2010) seamount-derived material comprising dismembered and mixed MORB- and OIB-type basalts and radiolarites has been found in ophiolites. However, seamounts typically demonstrate linear trends in multi-isotope plots as well as in isotopes vs. canonical trace-element ratios, resulting from a multicomponent mixing process involving some of the typical mantle end-members (e.g. EM-I, EM-II or HIMU). This type of isotopic variation is not observed in the Klepa basalts, in spite of variable trace-element ratios (Figure 2). Moreover, the identification of amphibole, apatite, ilmenite and garnet in the source implies the involvement of metasomatised lithospheric mantle with a thickness of $>90 \mathrm{~km}$. Oceanic lithosphere of this thickness would be typical of an old oceanic domain (Class \& Goldstein, 1997) but is not viable for the alleged Sava oceanic lithosphere, which is supposed to be younger than $160 \mathrm{Ma}$.

2. Our preferred model is that the continental mantle has played a major role in the origin of the Klepa basalts. In this model Klepa magma is generated by extension-driven partial melting at the asthenosphere-lithosphere boundary. This model can explain geochemical variations that result from polybaric melting of the relatively homogeneously metasomatised continental lithospheric mantle by migration of the locus of magma generation from the garnet to the spinel stability field. These melting paths are consistent with adiabatically ascending normal-temperature asthenosphere beneath an extensively thinned and metasomatised 
continental lithosphere: heat supply from the asthenosphere will induce partial melting in the most fertile parts of the lithospheric mantle, resulting in the basaltic magmatism (e.g. Pilet, 2015 and references therein).

\section{4 | Geodynamic implications}

Our preferred model implies that the Klepa basalts formed by intracontinental volcanism triggered by extension and elevated heat flow, which tapped the continental rather than the oceanic mantle lithosphere. In other words, the Klepa block does not represent ophiolite remnants of an alleged Late Cretaceous oceanic domain. In the following, we outline possible scenarios for the origin of the Klepa magmatism, taking into account two substantially different views on the Cretaceous large-scale regional development for two end-membertype settings:

I. The Sava Zone comprises the remnants of the youngest Neotethyan ocean, which remained open until the latest Cretaceous (Gallhofer et al. 2015; Schmid et al., 2008; Ustaszewski et al., 2009, 2010). In this scenario, the Sava zone is part of an accretionary wedge whose northern segment is present in N Bosnia (see Figure 1, locality 1 of inset map) and which underwent amphibolite-grade metamorphism at around $65 \mathrm{Ma}$. The strongest argument for this model is the existence of the Late Cretaceous Apuseni-Banat-Timok-Srednjegorje magmatic and metallogenic belt further eastward (Berza, Constantinescu, \& Vlad, 1998; Ciobanu, Cook, \& Stein, 2002; Gallhofer et al., 2015; von Quadt, Moritz, Peytcheva, \& Heinrich, 2005). In view of the subduction-type geochemistry shown by these rocks and their association with typical porphyry copper deposits, many authors interpret this belt as a magmatic arc installed onto the European continent during the north-eastward subduction of oceanic lithosphere, that is, the Sava Ocean, in an Andean-type scenario (Gallhofer et al., 2015; Kolb et al., 2012). If this scenario were applicable, the magmatism along the Sava zone would be situated within the forearc region of the European upper plate, which is traditionally considered to be cold and generally amagmatic. Exceptional volcanism would be confined to zones of local extension within arc-front, forearc and accretionary prism settings, and would be controlled by ridge subduction and subsequent slab window formation (Cole \& Stewart, 2009; Wilson, McCrory, \& Stanley, 2005), similar to the volcanic fields of western California and southern Alaska where occasional adakites occur beside basalts. If applied to the Sava Zone, such a scenario could explain the broad contemporaneity of arc magmatism in the Late Cretaceous Apuseni-Banat-Timok-Srednjegorje magmatic and metallogenic belt with magmatism in the Klepa block located near the trench.

II. The Sava Zone delimits a diffuse tectonic boundary between Adria and Europe, which had already collided in the late Jurassic (Csontos \& Vörös, 2004). Regional subsidence resulted in peneplanisation during the late Jurassic and formation of lateritic crust and bauxites, suggesting that the whole region was potentially a continental environment at that time. Both sides of the Sava Zone, that is, the Lower Pelagonian unit (Kilias et al., 2010) and the Dacia unit (Reiser, Schuster, Spikings, Tropper, \& Fügenschuh, 2016), have been overprinted by Early Cretaceous regional metamorphism, which is not easy to understand if the two areas were separated by an open ocean at that time. Furthermore, the absence of Early/Late Cretaceous ophiolites in the Balkans together with Late Jurassic ages of metamorphic soles all over the Balkan Peninsula (Borojević Šoštarić et al., 2014 and references therein) seem to indicate that convergence and ocean closure took place during the Late Jurassic. The overall evidence is far from clear-cut, however, because Early Cretaceous metamorphism at the Adriatic margin could be related to an obduction event rather than to continental collision (Tremblay, Meshi, Deschamps, Goulet, \& Goulet, 2015) and the absence of the remnants of the Sava Ocean could be due to complete subduction of the oceanic lithosphere at the end of the Cretaceous. Nevertheless, if scenario II is applicable, the mafic rocks of the Klepa area may represent intracontinental volcanism related to transtensional tectonics. Discrete magmatic centres along the Sava zone include Moslovačka Gora (Starijaš, Gerdes, Balen, Tibljas, \& Finger, et al. 2010), Požeška Gora (Pamić \& Šparica, 1983) and Prosara (Ustaszewski et al., 2010) in Croatia, Kozara (Ustaszewski et al., 2009) in Bosnia and Tešića Majdan (Prelević, Wehrheim, Božović, Romer, \& Boev, 2014) in Serbia (Figure 1). The origin and geodynamic significance of these centres have been considered either enigmatic (Ustaszewski et al., 2009) or clearly not ophiolitic (Cvetković et al., 2014). These centres, however, may have developed in a similar setting to the Klepa basalts, with which they are coeval. Analogous geodynamic situations worldwide occur along the north and east Anatolian faults (Hubert-Ferrari et al., 2009; Tatar et al., 2007) and in the pull-apart basins in the western United States (Tibaldi, Pasquarè, \& Tormey, 2010) where magmatic products demonstrate similar geochemical affinity.

\section{6 | CONCLUSIONS}

The Klepa volcanic rocks demonstrate the geochemical signature of basalts derived from continental lithosphere rather than of basalts from typical oceanic crust. This geochemical signature agrees well with other geological observations including the absence of other ophiolite members, especially those more typical of "normal" oceanic crust such as MORB/BAB rocks. In the context of Cretaceous largescale regional development, magmatism in the Sava Zone may have been generated either within a fore-arc of an active Andean-type subduction due to ridge subduction, or along a diffuse transtensional tectonic boundary between Europe and Africa, which had collided earlier.

\section{ACKNOWLEDGEMENTS}

This study was supported by the University of Mainz Forschungs fond for D.P., the Serbian Ministry of Education, Science and 
Technological Development (project no. 176016) and the Serbian Academy of Sciences and Arts (F17 and F9) for D.P. and V.C. The authors thank two anonymous reviewers for reading one of the earlier versions of the manuscript, and Professor Klaus Mezger for handling our manuscript.

\section{REFERENCES}

Antić, M., Peytcheva, I., von Quadt, A., Kounov, A., Trivić, B., Serafimovski, T., ... Wetzel, A. (2016). Pre-Alpine evolution of a segment of the North-Gondwanan margin: Geochronological and geochemical evidence from the central Serbo-Macedonian Massif. Gondwana Research, 36, 523-544.

Beier, C., Stracke, A., \& Haase, K. M. (2007). The peculiar geochemical signatures of Sao Miguel (Azores) lavas: Metasomatised or recycled mantle sources? Earth and Planetary Science Letters, 259, 186199.

Berza, T., Constantinescu, E., \& Vlad, S. N. (1998). Upper Cretaceous magmatic series and associated mineralisation in the Carpathian Balkan Orogen. Resource Geology, 48, 291-306.

Borojević Šoštarić, S., Palinkaš, A. L., Neubauer, F., Cvetković, V., Bernroider, M., \& Genser, J. (2014). The origin and age of the metamorphic sole from the Rogozna Mts., Western Vardar Belt: New evidence for the one-ocean model for the Balkan ophiolites. Lithos, 192-195, 39-55.

Božović, M., Prelević, D., Romer, R. L., Barth, M., Van den Bogaard, P., \& Boev, B. (2013). The Demir Kapija Ophiolite, Macedonia (FYROM): A Snapshot of Subduction Initiation within a Back-arc. Journal of Petrology, 54, 1427-1453.

Cebria, J. M., Lopez, R. J., Doblas, M., Oyarzun, R., Hertogen, J., \& Benito, R. (2000). Geochemistry of the Quaternary alkali basalts of Garrotxa (NE Volcanic Province, Spain); a case of double enrichment of the mantle lithosphere. Journal of Volcanology and Geothermal Research, 102, 217-235.

Cebria, J. M., \& Lopez Ruiz, J. (1996). A refined method for trace element modelling of nonmodal batch partial melting processes; the Cenozoic continental volcanism of Calatrava, central Spain. Geochimica Et Cosmochimica Acta, 60, 1355-1366.

Ciobanu, C. L., Cook, N. J., \& Stein, H. (2002). Regional setting and geochronology of the Late Cretaceous Banatitic Magmatic and Metallogenetic Belt. Mineralium Deposita, 37, 541-567.

Class, C., \& Goldstein, S. L. (1997). Plume-lithosphere interactions in the ocean basins: Constraints from the source mineralogy. Earth and Planetary Science Letters, 150, 245-260.

Cole, R. B., \& Stewart, B. W. (2009). Continental margin volcanism at sites of spreading ridge subduction: Examples from southern Alaska and western California. Tectonophysics, 464, 118-136.

Csontos, L., \& Vörös, A. (2004). Mesozoic plate tectonic reconstruction of the Carpathian region. Palaeogeography, Palaeoclimatology, Palaeoecology, 210, 1-56.

Cvetković, V., Downes, H., Prelević, D., Jovanovic, M., \& Lazarov, M. (2004). Characteristics of the lithospheric mantle beneath East Serbia inferred from ultramafic xenoliths in Palaeogene basanites. Contributions to Mineralogy and Petrology, 148, 335-357.

Cvetković, V., Prelević, D., \& Schmid, S. (2016). Geology of South-Eastern Europe. In P. Papić (Ed.), Mineral and thermal waters of Southeastern Europe (pp. 1-29). Springer International Publishing.

Cvetković, V., Šarić, K., Grubić, A., Cvijić, R., \& Milošević, A. (2014). The Upper Cretaceous ophiolite of North Kozara - remnants of an anomalous mid-ocean ridge segment of the Neotethys? Geologica Carpathica, 65, 117-130.

Ellam, R. M. (1992). Lithospheric thickness as a control on basalt geochemistry. Geology, 20, 153-156.
Frost, D. J. (2006). The Stability of Hydrous Mantle Phases. Reviews in Mineralogy \& Geochemistry, 62, 1, 243-271.

Fu, B., Bence, P., Bröcker, C. J., \& Bulle, F. (2012). O-Hf isotope constraints on the origin of zircons in high-pressure mélange blocks and associated matrix rocks from Tinos and Syros, Greece. European Journal of Mineralogy, 24, 277-287.

Gallhofer, D., von Quadt, A., Peytcheva, I., Schmid, S. M., \& Heinrich, C. A. (2015). Tectonic, magmatic, and metallogenic evolution of the Late Cretaceous arc in the Carpathian-Balkan orogen. Tectonics, 34, 18131836.

Grubić, A., \& Ercegovac, M. (1974). L age des couches de Veles et leurs importance pour líexplication de líevolution de la zone du Vardar. Comptes Rendus des Séances de la Societé Serbe de Géologie, 183-201.

Hubert-Ferrari, A., King, G., Van Der Woerd, J., Villa, I., Altunel, E., \& Armijo, R. (2009). Long-term evolution of the North Anatolian Fault: New constraints from its eastern termination. Geological Society, London, Special Publications, 311, 133-154.

Ionov, D. A., Bodinier, J.-L., Mukasa, S. B., \& Zanetti, A. (2002). Mechanisms and sources of mantle metasomatism: Major and trace element compositions of peridotite xenoliths from Spitsbergen in the context of numerical modelling. Journal of Petrology, 43, 2219-2259.

Ionov, D. A., Gregoire, M., \& Prikhodko, V. S. (1999). Feldspar-Ti-oxide metasomatism in off-cratonic continental and oceanic upper mantle. Earth and Planetary Science Letters, 165, 37-44.

John, T., Scherer, E. E., Schenk, V., Herms, P., Halama, R., \& GarbeSchonberg, D. (2010). Subducted seamounts in an eclogite-facies ophiolite sequence: The Andean Raspas Complex, SW Ecuador. Contributions to Mineralogy and Petrology, 159, 265-284.

Karamata, S. (2006). The geological development of the Balkan Peninsula related to the approach, collision and compression of Gondwanan and Eurasian units. Geological Society, London, Special Publications, 260, 155-178.

Kilias, A., Frisch, W., Avgerinas, A., Dunkl, I., Falalakis, G., \& Gawlick, H.-J. (2010). Alpine architecture and kinematics of deformation of the northern Pelagonian nappe pile in the Hellenides. Austrian Journal of Earth Sciences, 103, 4-28.

Klemme, S. (2004). The influence of $\mathrm{Cr}$ on the garnet-spinel transition in the Earth's mantle: Experiments in the system $\mathrm{MgO}-\mathrm{Cr}_{2} \mathrm{O}_{3}-\mathrm{SiO}_{2}$ and thermodynamic modelling. Lithos, 77, 639-646.

Kolb, M., Von Quadt, A., Peytcheva, I., Heinrich, C. A., Fowler, S. J., \& Cvetković, V. (2012). Adakite-like and normal arc magmas: Distinct fractionation paths in the East Serbian segment of the Balkan-Carpathian arc. Journal of Petrology, 54, 421-451.

Kossmat, F. (1924). Geologie der zentralen Balkanhalbinsel, mit einer Übersicht des dinarischen Gebirgsbaus. Berlin: Verlag Gebrüder Bornträger.

Langosch, A., Seidel, E., Stosch, H.-G., \& Okrusch, M. (2000). Intrusive rocks in the ophiolitic mélange of Crete - Witnesses to a Late Cretaceous thermal event of enigmatic geological position. Contributions to Mineralogy and Petrology, 139, 339-355.

Maaløe, S., \& Pedersen, R.B., (2003). Two methods for estimating the degree of melting and trace element concentrations in the sources of primary magmas. Chemical Geology, 193, 155-166.

Marroni, M., Pandolfi, L., Saccani, E., \& Zelić, M. (2004b). Boninites from the Kopaonik area (Southern Serbia): new evidences for suprasubduction ophiolites in the Vardar zone. Ofioliti, 29, 251-254.

McDonough, W. F. (1990). Constraints on the composition of the continental lithospheric mantle. Earth and Planetary Science Letters, 101, 1-18.

McKenzie, D., \& O'Nions, R. K. (1991). Partial melt distributions from inversion of rare earth element concentrations. Journal of Petrology, 32, 1021-1091.

O'Reilly, S. Y., \& Griffin, W. L. (2000). Apatite in the mantle: Implications for metasomatic processes and high heat production in Phanerozoic mantle. Lithos, 53, 217-232. 
Pamić, J., \& Šparica, M. (1983). The age of the volcanic rocks of Požeška Gora (Croatia, Yugoslavia). Radovi Jugoslavenske Akademije Znanosti i Umjetnosti, 404, 183-198.

Pearce, J. A. (2008). Geochemical fingerprinting of oceanic basalts with applications to ophiolite classification and the search for Archean oceanic crust. Lithos, 100, 1448

Pearce, J. A., \& Peate, D. W. (1995). Tectonic Implications of the Composition of Volcanic Arc Magmas. Annual Review of Earth and Planetary Sciences, 23, 251-285.

Pilet, S. (2015). Generation of low-silica alkaline lavas: Petrological constraints, models, and thermal implications. In G. R. Foulger, M. Lustrino \& S.D. King (Eds.), The Interdisciplinary Earth: A Volume in Honor of Don L. Anderson. Geological Society of America Special Paper 514 and American Geophysical Union Special Publication 71, 281-304.

Popević, A., Memović, E., Zakariadze, G., Milovanović, D., \& Karamata, S. (2005). The basalts of Podpeć (near Priboj, SW Serbia), the youngest (?) basaltic rocks of the Dinaridic ophiolitic basin. Geologica Balcanica, 34, 3-4.

Prelević, D., Wehrheim, S., Božović, M., Romer, R., \& Boev, B. (2014). The origin of volcanic section of the Vardar ophiolitic zone: A comparative petrological and geochemical study of latecretaceous volcanics from Macedonia with their jurasic counterparts from Balkans. In V. Cvetković (Ed.), XVI Serbian Geological Congress (pp. 227-230). Donji Milanovac: Serbian Geological Society.

Reiser, M. K., Schuster, R., Spikings, R., Tropper, P., \& Fügenschuh, B. (2016). From nappe stacking to exhumation: Cretaceous tectonics in the Apuseni Mountains (Romania). International Journal of Earth Sciences, 1-27.

Robertson, A. H. F., \& Karamata, S. (1994). The role of subduction-accretion processes in the tectonic evolution of the Mesozoic Tethys in Serbia. Tectonophysics, 234, 73-94.

Robertson, A., Karamata, S., \& Šarić, K. (2009). Overview of ophiolites and related units in the Late Palaeozoic-Early Cenozoic magmatic and tectonic development of Tethys in the northern part of the Balkan region. Lithos, 108, 1-36.

Robertson, A. H. F., Trivić, B., Đerić, N., \& Bucur, I. I. (2013). Tectonic development of the Vardar ocean and its margins: Evidence from the Republic of Macedonia and Greek Macedonia. Tectonophysics, 595596, 25-54.

Saccani, E., Bortolotti, V., Marroni, M., Pandolfi, L., Photiades, A., \& Principi, G. (2008). The Jurassic association of backarc basin ophiolites and calc-alkaline volcanics in the Guevgueli complex (Northern Greece): Implication for the evolution of the Vardar zone. Ofioliti, 33, 209-227.

Schmid, S. M., Bernoulli, D., Fugenschuh, B., Matenco, L., Schefer, S., Schuster, R., ... Ustaszewski, K. (2008). The Alpine-CarpathianDinaridic orogenic system: Correlation and evolution of tectonic units. Swiss Journal of Geosciences, 101, 139-183.

Şengör, A. M. C., \& Yılmaz, Y. (1981). Tethyan evolution of Turkey: A plate tectonic approach. Tectonophysics, 75, 181-241.

Shaw, D. M. (1970). Trace element fractionation during anatexis. Geochimica Et Cosmochimica Acta, 34, 237-243.

Starijaš, B., Gerdes, A., Balen, D., Tibljaš, D., \& Finger, F. (2010). The Moslavačka Gora crystalline massif in Croatia: A Cretaceous heat dome within remnant Ordovician granitoid crust. Swiss Journal of Geosciences, 103, 61-82.

Sun, S. S., \& McDonough, W. F. (1989). Chemical and isotopic systematics of oceanic basalts; implications for mantle composition and processes. In A. D. Saunders, \& M. J. Norry (Eds.), Magmatism in the ocean basins (pp. 313-345). London, United Kingdom: Geological Society of London, 313-345.

Tatar, O., Yurtmen, S., Temiz, H., Gursoy, H., Kocbulut, F., Mesci, B. L., \& Guezou, J. C. (2007). Intracontinental Quaternary Volcanism in the
Niksar Pull-Apart Basin, North Anatolian Fault Zone, Turkey. Turkish Journal of Earth Sciences, 16, 417-440.

Tibaldi, A., Pasquarè, F., \& Tormey, D. (2010). Volcanism in reverse and strike-slip fault settings. In J. Negendank, \& S. Cloetingh (Eds.), New frontiers in integrated solid earth sciences (pp. 315-348). Dordrecht, Netherlands: Springer.

Tremblay, A., Meshi, A., Deschamps, T., Goulet, F., \& Goulet, N. (2015). The Vardar zone as a suture for the Mirdita ophiolites, Albania: Constraints from the structural analysis of the Korabi-Pelagonia zone. Tectonics, 34, 352-375.

Treuil, M., \& Joron, J. L. (1975). Utilisation des elements hydromagmatophiles pour la simplification de la modelisation quantitative des processus magmatiques; exemples de l'Afar et la Dorsale Medioatlantique. Societa Italiana di Mineralogia e Petrologia; Atti della Riunione; tavola rotonda, Geochimica e Geochemica Isotopica, 31, 125-174.

Ustaszewski, K., Kounov, A., Schmid, S. M., Schaltegger, U., Krenn, E., Frank, W., \& Fügenschuh, B. (2010). Evolution of the Adria-Europe plate boundary in the northern Dinarides: From continent-continent collision to back-arc extension. Tectonics, 29, TC6017.

Ustaszewski, K., Schmid, S. M., Lugović, B. K., Schuster, R., Schaltegger, U., Bernoulli, D., ... Schefer, S. (2009). Late Cretaceous intra-oceanic magmatism in the internal Dinarides (northern Bosnia and Herzegovina): Implications for the collision of the Adriatic and European plates. Lithos, 108, 106-125.

van Hinsbergen, D. J. J., \& Schmid, S. M. (2012). Map view restoration of Aegean-West Anatolian accretion and extension since the Eocene. Tectonics, 31, TC5005.

Vaselli, O., Downes, H., Thirlwall, M., Dobosi, G., Coradossi, N., Seghedi, I., Szakacs, A., \& Vannucci, R. (1995). Ultramafic Xenoliths in PlioPleistocene Alkali Basalts from the Eastern Transylvanian Basin: Depleted Mantle Enriched by Vein Metasomatism. Journal of Petrology, 36, 23-53.

von Quadt, A., Moritz, R., Peytcheva, I., \& Heinrich, C. A. (2005). Geochronology and geodynamics of Late Cretaceous magmatism and $\mathrm{Cu}-\mathrm{Au}$ mineralization in the Panagyurishte region of the ApuseniBanat-Timok-Srednogorie belt, Bulgaria. Ore Geology Reviews, 27, 95-126.

Wilson, D. S., McCrory, P. A., \& Stanley, R. G. (2005). Implications of volcanism in coastal California for the Neogene deformation history of western North America. Tectonics, 24, TC3008.

Yang, G., Li, Y., Xiao, W., \& Tong, L. (2015). OlB-type rocks within West Junggar ophiolitic mélanges: Evidence for the accretion of seamounts. Earth-Science Reviews, 150, 477-496.

Zindler, A., \& Hart, S. (1986). Chemical geodynamics. Annual Review of Earth and Planetary Sciences, 14, 493-571.

\section{SUPPORTING INFORMATION}

Additional Supporting Information may be found online in the supporting information tab for this article.

How to cite this article: Prelević D, Wehrheim S, Reutter M, et al. The Late Cretaceous Klepa basalts in Macedonia (FYROM) - Constraints on the final stage of Tethys closure in the Balkans. Terra Nova. 2017;29:145-153. https://doi.org/ 10.1111/ter.12264 